\title{
The Factors Affecting the Adoption of e-PACRA Services through the Government Service Bus
}

\author{
Gift Kozo Mwinga1, Jackson Phiri² \\ ${ }^{1}$ Graduate School of Business, University of Zambia, Lusaka, Zambia \\ ${ }^{2}$ Department of Computer Sciences, School of Natural Sciences, University of Zambia, Lusaka, Zambia \\ Email:kozogm@gmail.com, Jackson.phiri@cs.unza.zm
}

How to cite this paper: Mwinga, G. K., \& Phiri, J. (2022). The Factors Affecting the Adoption of e-PACRA Services through the Government Service Bus. Open Journal of Business and Management, 10, 402-423. https://doi.org/10.4236/ojbm.2022.101024

Received: November 4, 2021

Accepted: January 24, 2022

Published: January 27, 2022

Copyright $\odot 2022$ by author(s) and Scientific Research Publishing Inc. This work is licensed under the Creative Commons Attribution International License (CC BY 4.0).

http://creativecommons.org/licenses/by/4.0/

\begin{abstract}
The study was conducted to establish the factors affecting the adoption of e-PACRA services through the Government Service Bus. The UTAUT model was used as the conceptual framework to generate five hypotheses and the survey questionnaires which were analyzed after data collection and findings. The study assessed challenges of e-PACRA services on the Government Service Bus under the Smart Zambia Institute in order to ascertain and identify whether adoption of electronic services was affected by the five constructs of the UTAUT Model. The Cochrane's Formula was used to derive the sample size of 132. The survey location for the study was Lusaka City in Zambia. Both qualitative and quantitative data were collected from respondents at a $100 \%$ response using the structured questionnaire. The output of the data was analyzed by SPSS and the ANOVA test was used to determine the relationship between variables. Three out of the 5 hypotheses were accepted as they showed a statistical relationship between the variables. The measure of the $p$-value was at $\leq 0.05$.
\end{abstract}

\section{Keywords}

e-PACRA, Government Service Bus, UTAUT Model

\section{Introduction}

E-Government has been adapted in many countries the world over as the provision of services moves even more to electronic means on the internet. "E-Government in Zambia can be traced way back to 1993" (Chipeta, 2018) and can be "defined as the delivery of improved services to citizens, businesses and other members of society through drastically changing the way governments manage information" (Kumar et al., 2007). However, the internet is vast and can be likened to the wild west. It is therefore prudent that specific secure and controlled solutions through 
government internet portals have been set up for delivery of services to the public in general. One such solution is the Government Service Bus, which is a public sector administrative and payment solution on the e-Government platform. It has become overly vital to identify and quantify the usage of these online services to not only ascertain the return on investment but also provide a platform that will widen client access, ease of use, and deliberately enhance the synergy of government ministries, agencies, and semi-autonomous institutions for improved, efficient, transparent, and cost-effective delivery of services. PACRA's annual report (PACRA, 2020), introduced four (4) of its services on the Government Service Bus (GSB). The Government Service Bus is a public administrative and payment online platform on which services are offered by government departments and statutory bodies and can be accessed by the general public (Smart Zambia Institute, 2020). This Government Service Bus platform was developed by Smart Zambia Institute in collaboration with the Ministry of Finance, with the primary agenda of providing an administratively effective online system with so many operational modules of service to the general public, with due emphasis on online payment capabilities in Zambia. However, the GSB has many modular functions which it hopes to incorporate through the Smart Zambia e-governance transformative agenda. Technically, the government service bus would provide a more robust, secure, and trustworthy platform to deliver electronic services.

According to (Office of the Vice President, 2019) ministerial statement on the progress of Smart Zambia, estimates of reduction in paper usage were evident, costs of broadband internet access were also significantly reduced, and the move to more electronic means further improved revenue collection and reduced audit queries, making government institutions more efficient in their operations and service delivery, enhancing accountability (The World Bank, 2020), and also positively impact the social and economic status of Zambia as a country. The system will also look to gain far and wide access as the network platform spreads all across the country.

This should translate into more customers gaining access, higher traffic culminating in higher revenue for institutions like PACRA. The objectives are therefore to investigate and identify factors that impede PACRA customers from using e-PACRA services through the GSB and to assess the challenges PACRA customers have in using e-PACRA services through the GSB. The GSB will increasingly improve the use and access of the e-PACRA services by the general public. These services will not only benefit customers but government interrelated institutions and provide transparency and reduce corruption and theft, thereby impacting government coffers in a positive way.

The transformation from manual and physical means to access and provide e-PACRA services has since evolved to electronic means through the e-government platform. It is on this Government Service Bus that e-PACRA users can transact using various payment platforms like Airtel, MTN, Zamtel, and even debit cards.

The research will bring to the fore the factors affecting the adoption of e-PACRA 
services through the GSB. This will set a basis for improvement of access, customer satisfaction and better delivery of services by PACRA. The study will therefore determine the reasons why customers will or will not use the e-PACRA services on the Government Service Bus (GSB) by using the Unified Theory of Acceptance and Use of Technologies (UTAUT) Model as a framework.

The Government Service Bus (GSB), where e-PACRA services occur, is an innovative solution that "aids smooth exchange of data among government entities" (TDRA, 2021), so as to provide services to the public. The UTAUT model adapted "explains about $70 \%$ of the variance in usage intention (Martins et al., 2014) and $50 \%$ of the variance in actual usage" (Daka \& Phiri, 2019), which is significant compared to the eight original models. According to Cheng, "the UTAUT model is the most effective model for analyzing technology acceptance" (Chao, 2019). The study therefore brings attention to e-PACRA services to provide specific insight on matters of adoption of these services. The lack of technological know-how as well as educational gaps are among the challenges (Lishomwa \& Phiri, 2020). "In fact, less than half of 700,000 people may be even aware of e-Government in Zambia" (Bwalya \& Healy, 2010). It is estimated that e-government services as of 2020 , "only $17.34 \%$ of individuals had access to the Internet or online services in Zambia, compared to the world average of 43.34\%" (Sikaonga \& Tembo, 2020).

The study therefore provides a unique position to assess the factors that affect the adoption of e-PACRA services through the Government Service Bus because of its evident low uptake of e-PACRA services on the e-government platform.

\section{Key Literature Review}

Table 1 gives a summary of the gaps in the literature review that was conducted in this research study.

Table 1. Literature review summary.

\begin{tabular}{|c|c|c|c|c|}
\hline No. & Author & Focus of Study & Findings & Gaps \\
\hline 1 & $\begin{array}{l}\text { Chipeta J. } \\
\text { (2018). }\end{array}$ & $\begin{array}{l}\text { To review e-government } \\
\text { development in Zambia } \\
\text { analyzing readiness to sustain } \\
\text { e-services and investigate } \\
\text { different e-government } \\
\text { development frameworks and } \\
\text { models. }\end{array}$ & $\begin{array}{l}\text { E-government promotes open } \\
\text { government data and makes } \\
\text { government information easily } \\
\text { accessible for public consumption } \\
\text { at } 29 \% \text { opportunities and } 71 \% \\
\text { challenges to successfully } \\
\text { implement and support e-services. }\end{array}$ & $\begin{array}{l}\text { The provision of e-governance } \\
\text { services comparison is skewed as the } \\
\text { study considered implementations in } \\
\text { more advanced countries outside } \\
\text { Africa e.g. United Kingdom and USA } \\
\text { that have vast experience. The study } \\
\text { should have narrowed down on } \\
\text { countries at the same level. }\end{array}$ \\
\hline 2 & $\begin{array}{l}\text { Bwalya KJ \& } \\
\text { Healy (2010). }\end{array}$ & $\begin{array}{l}\text { To examine how } \\
\text { e-Government has been } \\
\text { harnessed in Botswana and } \\
\text { Zambia for social inclusion. }\end{array}$ & $\begin{array}{l}\text { A conceptual e-Government } \\
\text { adoption model that extends } \\
\text { Davis' TAM to include other } \\
\text { attributes and constructs were } \\
\text { found to be relevant to the local } \\
\text { context of SADC. Proposed } \\
\text { model creates premise for future } \\
\text { adoption of e-Government in the } \\
\text { SADC region. }\end{array}$ & $\begin{array}{l}\text { The study was mostly based on } \\
\text { literature and no research engagements } \\
\text { were conducted on the ground to } \\
\text { ascertain any of the theories. As a } \\
\text { limitation, the model had not been } \\
\text { formally empirically tested or } \\
\text { validated to confirm the anticipated } \\
\text { benefits. That it has to offer and its } \\
\text { appropriateness to SADC. }\end{array}$ \\
\hline
\end{tabular}


Daka, G. C. \&

Phiri, J. (2019).
To provide a solution in driving formal banking services uptake in the most cost-effective, easy and convenient way, to both the customers as well as the banks.
Using the UTAUT model, only Social Influence (SI) was not significant to the user's intention to adopt e banking services.
The demographical (Age, Gender, Experience and Voluntariness of use) aspect of the study was not adequately addressed.

\section{To assess all Zambian}

Sikaonga, S. \& government ministries

4 Tembo S. (2020). embrace e-Governance but -Government readiness in the almost $50 \%$ of the sample civil service with regard to e-Gov implementation.
Most civil servants were university graduates ready to believed Government didn't do enough to sell the e-Gov agenda to the public.
The study was restricted to the Ministry headquarters which generalized results. Need to expand study to provinces and districts is vital. The study also generalized factors pertaining to policy and the will to implement systems needed to be examined.
E-Banking as a Tool: Whether Value proposition of E-Banking Nuwagaba, A. \& Internet Banking could be 5 Ngoma, B. used to improve Banking (2014) products and service delivery to Customers was strong and would lead to greater positive change in Banking service delivery and customer satisfaction.
Central bank as a source was too generalized to prove that E-Banking could be used as a tool to improve banking services to customers. Central bank has specific roles with limited clientele.

This Paper aimed to review IT adoption literature concerning validation and development of

To examine Acceptance and Usage of open access within 6 Ahmad M.I public universities using the (2014) full version of UTAUT based open access adoption model.
The findings show that UTAUT is found to be applicable to some extent in the educational setting, but might need a few modifications to fit the context.
To examine the challenges encountered in e-government implementation, as well as the potential opportunities available in the context of Botswana society.
The findings and implications of this study reveal Botswana was still lagging behind in utilizing information and communication technologies for delivering government services online.
Unified Theory of Acceptance and

Use of Technology (UTAUT).

However, other moderators come in to play. Theory validation and adaptation is applied in different settings provide inconsistencies depending on circumstances of the environment of the sample.
The research study was more literature related as opposed to practically engaging with respondents in Botswana. It mostly examination and analyzed Botswana's published e-government vision and strategy as presented, together with a review of other relevant literature.
How to capture corporate

8 Lishomwa L. \& customers dealing in forex Phiri J. (2020). transactions through Internet Bank Services.
A very strong relationship between internet banking and performance expectation, control factor and social influence was found to exist.
Skewed study mostly focused on corporate customers who dealt in forex while Internet Banking Services cut across many other customers. 


\subsection{Conceptual Framework and Theoretical Framework}

\section{CONCEPTUAL FRAMEWORK}

DThroughreview of the UTAUT model, it was identified as an effective tool to as sessthe factorsaffectinge-PACRA servicesthrough the GSB as it was technologybasedwith differentfa cets with regardto users (Venkateshet al., 2003).

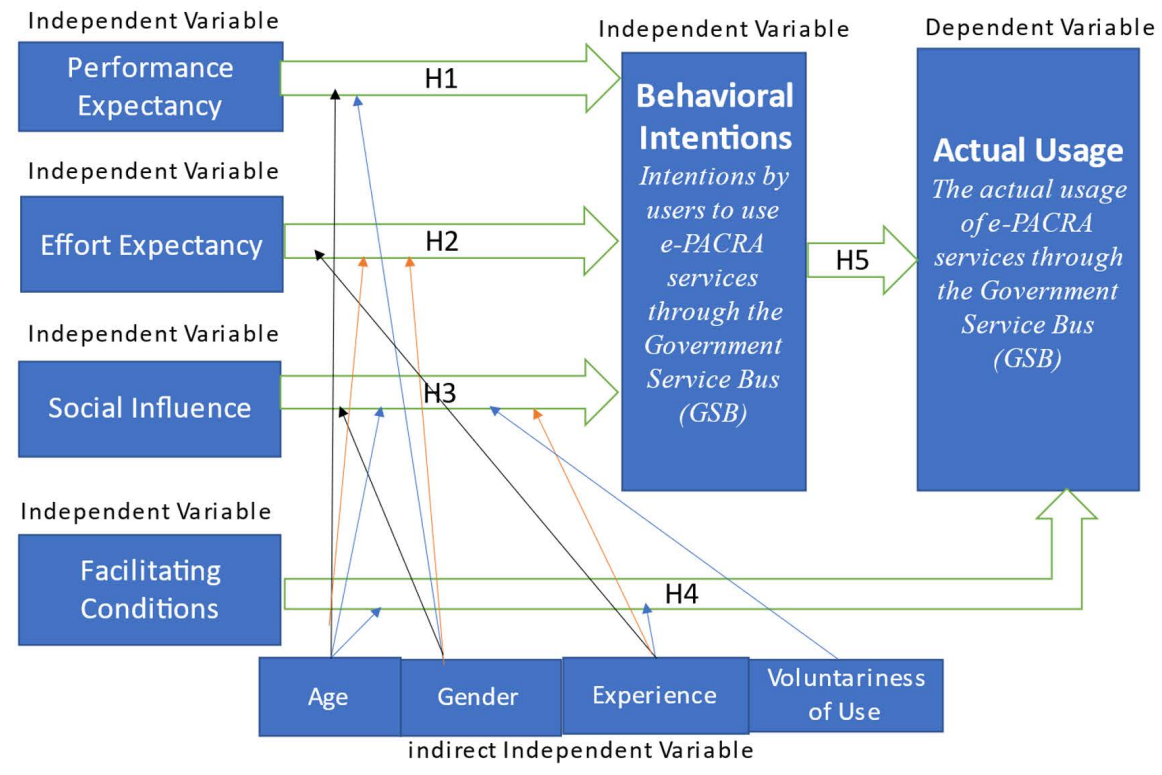

\subsection{Theoretical Framework}

According to Al-Qeisi (2018), technology acceptance research is a constantly developing field. The disciplines that contributed to its development are either belief-focused or system-focused. The unified theory of acceptance and use of technology (UTAUT) combined both. The current research model proposes an extension to the UTAUT that accounts for online usage behavior. The proposed research model was tested in two countries (UK and Jordan) to investigate the viability of the unified model of technology acceptance in different boundaries as a model of individuals' discretionary usage of Internet banking. The study also questions the roles of other determinants and moderators in this context. Results found support for the effect of the proposed extension, website quality perceptions, on usage behavior in both countries' models; the total effect of this extension exhibited website quality perceptions as the most influential determinant of usage behavior in both models, and the performance expectancy construct was second in effect.

According to Ajzen (1991), social influence had no impact on the usage behavior in both models, which is consistent with previous research that advocates a declining role of social influence under discretionary usage and increased experience conditions. Furthermore, the moderating role of performance expectancy previously established in TAM's research was supported in the UTAUT model in both countries' models. Moreover, both models reported a non-moderating effect of gender, which is also in line with recent research findings that suggest declining gender differences under voluntary usage conditions and advanced 
experience. Education and income were moderators only for the UK model. Although the research findings demonstrated that both countries' models were "configurable" similar with respect to model specifications, the models' explanatory power for usage behavior was dissimilar: the UK's model explanatory power exceeded that of Jordan's model, presenting an opportunity for future research. The current research contributes to knowledge in the field of technology acceptance research. It demonstrated that website quality perceptions, as a multidimensional concept, play an important role in the online usage context. It also demonstrated that the unified model of technology acceptance established in the western culture could be transferred to a non-western culture, although with varying degrees of explanation power (Ajzen, 1991).

\subsection{Hypothesis Formulation}

The UTAUT was therefore adapted for generating hypotheses used in this study. The main moderators or predictors were PE, EE, SI, FC and BI.

Source: Ajzen (1991).

\section{Hypothesis Statements}

$\mathrm{H}_{1}$ There is a positive relationship between performance expectancy adoption and the use of e-PACRA services through the government services bus (GSB) by users.

$\mathrm{H}_{2}$ There is a positive relationship between effort expectancy adoption and the use of e-PACRA services through the Government Service Bus (GSB) by users.

$\mathrm{H}_{3}$ There is a positive relationship between social influence adoption and the use of e-PACRA services through the Government Service Bus (GSB) by users.

$\mathrm{H}_{4}$ There is a positive relationship between facilitating conditions and the use of e-PACRA services through the Government Service Bus (GSB) by users.

$\mathrm{H}_{5}$ There is a positive relationship between behavioral intention and the use of e-PACRA services through the Government Service Bus (GSB) by users.

The hypotheses above were generated based on the UTAUT Model (Venkatesh et al., 2003), taking the PE, EE, SI, FC, and BI as independent variables and the adoption and actual use of e-PACRA services as the dependent variable.

\section{Research Methodology}

\subsection{Introduction}

This section presented the research methods such as the research design, sources of data, sample size, sampling methods as well as methods of data collection, reliability of data, validity of data and ethics that would be used in this study.

\subsubsection{Research Design}

The mixed method approach was used where both qualitative and quantitative data were obtained. The qualitative method helped to obtain in-depth information, while the quantitative helped generalize the results. The use of both qualitative and quantitative methods complemented each other in order to validate the 
methods that were used to realize the objectives of the research study.

\subsubsection{Source of Data}

Primary as well as secondary data sources were used. The primary data was collected from the entire research subject within the catchment area of the research task from which the sample size was selected from what was referred to as the target population. The target population would involve all PACRA clientele who use PACRA online services. Secondary data would also be obtained from relevant literature, including publications and reports on the effectiveness and efficiency of e-government services.

\subsubsection{Sample Size}

The Simple Random sampling technique was considered more representative of the total population as opposed to other sampling techniques because it wasn't focused on inviting participants based on their position level in the organization. It was focused on maximizing the number of eligible respondents. It was broadly based with an emphasis on PACRA clientele registering businesses as a core function of the institution (PACRA) and accessing other related services. The main site and location for the study was the One Stop Shop in Lusaka's CBD where questionnaires were distributed and collected.

The study adopted the Cochran's sample formula to estimate the sample of e-PACRA respondents that were subjected to survey questionnaires.

According to Cochran (1977) and Sarmah et al. (2013), the aim of the calculation was to determine an adequate sample size which could estimate results for the whole population with good precision. In other words, one had to draw inferences or generalize about the population from the sample data. The inference to be drawn was related to some parameters of the population such as the mean, standard deviation or some other features like the proportion of an attribute occurring in the population. It was noted that a parameter was a descriptive measure of some characteristics of the population, whereas if the descriptive measure was computed from the observations in the sample, it would be called a statistic, is constant for a population, but the corresponding statistic would vary from sample to sample. Statistical inference generally adopts one of the two techniques, namely, the estimation of population parameters or testing of a hypothesis.

Initial Cochran's formula:

$$
n_{0}=\frac{Z^{2} P q}{e^{2}}
$$

$Z=1.96$ at $95 \%$ confidence level and 5\% Margin of error or Significance error $(e)=0.05$, Probability of e-PACRA adoption $\&$ use assumed $50 \%$ which is 0.5

$$
P=0.5 \text { and } q=0.5
$$

$n_{0}=$ Initial Sample Size

The Cochrane's initial formula: $n_{0}=\frac{Z^{2} P q}{e^{2}}=\frac{1.96^{2}(0.5)(0.5)}{0.05^{2}}=384$ 
Initial sample size $n_{0}=384$.

According to PACRA, only 10,321 customers successfully registered businesses country wide in the year 2020 . Zambia has 10 provinces and at $20 \%$ as online PACRA users, each province was therefore estimated to have $N=10,321 / 10=$ 1032.1, being customer's registered businesses. The target population represented by letter $N$ was captured from the registered businesses divided by the 10 provinces, which roughly worked out to 1032.1 per province. At $20 \%$ as online PACRA customers, the target population $\mathrm{N}$ works out to approximately 206. By using the modified Cochran's formula below:

$$
n=\frac{n_{0}}{1+\frac{\left(n_{0}-1\right)}{N}}
$$

where $N=$ Target Population, with $N=206$, Taking $Z=$ Confidence level of $95 \%$ (1.96).

$e=$ Significance error or Margin of error at $0.05, n=$ sample size, $p=$ probability of e-PACRA adoption \& use (0.5) \& $q=0.5$.

The modified Cochran's formula for obtaining sample size is shown and calculated as below:

$$
n=\frac{n_{0}}{1+\frac{\left(n_{0}-1\right)}{N}}=\frac{384}{1+\frac{(384-1)}{206}}=131.7
$$

$n$ which represents Sample Size is rounded off to 132 .

$n=132$

Therefore, a sample of 132 respondents was deemed ideal for this research study.

\subsubsection{Methods of Data Collection}

A survey questionnaire and interview guide were used to collect the data. The interview guide had both structured and semi-structured interviews because it would help keep the focus as the interviewer was the one that had control and for it to be completed. Preliminary interviews also provided accurate screening as the individual respondents being interviewed were unable to provide false information during the screening questions such as gender, age, race etc. Therefore, interviews were used to collect data from the key respondents from the One Stop Shop site and the PACRA main office as complementary information in Lusaka, capturing a wide array of respondents without bias in the market. The survey questionnaire had a mixture of open-ended, semi-closed, and closed-ended questions. Survey questionnaires were also targeted at groups of anyone's choosing and managed in various ways, i.e., research assistants could pick on anyone provided they met the criteria as a respondent to fill in the hard copy survey questionnaire. Some general information was obtained from Smart Zambia Institute, PACRA offices, the general public and PACRA agents on the subject. The general information and assertions, however, were not inherently used 
in the research study as analysis and findings relied heavily on the survey questionnaire as the guide.

\subsubsection{Data Analysis}

Primary data was processed and analyzed using the Statistical Package for Social Scientists (SPSS Ver. 23). This package was used due to its impeccable propensity to quickly analyze large volumes of data gathered through various methods of research. Its ability to make difficult analytical tasks easier and to keep one from making mistakes or forgetting important details or items. A category is a set of criteria that are integrated around a theme (Creswell, 2012). The first step in content analysis would entail the construction of categories. Thus, after identifying the categories, data was coded. The coded data would offer some evidence about the dominant categories, attributes and trends. Some of the data were presented in narrative form. The results were analyzed using the Pearson's Correlation to determine the relationship between the predictors/moderators and the adoption and use of the e-PACRA services through the Government Service Bus (GSB).

\subsubsection{Reliability of Data}

The reliability of the data was achieved through two methods, such as the use of the inter-rater method, whereby the results of the researcher were compared with the results of the research assistant that was employed. The other method was the use of the internal consistency method where the questions and the responses were logically related and tallied.

\subsubsection{Validity of Data}

The validity of data determined would be applied to the research instrument by using the content validity. The content validity ensured that the research instrument was representative of the full content of the phenomenon under investigation. In addition, the content validity ensured that all the aspects of the subjects under investigation were covered.

\section{Ethical Considerations}

The research study was purely and exclusively academic and any consequential outcome would be treated as such. Therefore, the contents and findings were not to be used in any way for any other purposes other than academics. Further, the maximum code of ethics was followed by getting consent from all the respondents. There was no coercion or influence to participate in the research study. All rights and confidentiality of all participants were strictly observed by ensuring anonymity in the interviews and only codes for the analysis of all information were used; no information could be traced back to any individual respondent.

\section{Demographics and Results Discussion}

\subsection{Demographic Profile of Respondents}

The demographic information includes the following characteristics of partici- 
pants: gender, marital status, age group, highest level of education, and type of employment. The demographics information is represented in Table 2 below based on frequency distributions and percentages. From the 132 respondents in this study, 85 (64.4\%) are male and 47 (35.6\%) are females. The calculated mean

Table 2. Demographic profile of respondents.

\begin{tabular}{ccc}
\hline Variable & Frequency & Percentage \\
\hline Gender & & \\
Male & 85 & 64.4 \\
Female & 47 & 35.6 \\
Total & 132 & 100.0 \\
\hline
\end{tabular}

\begin{tabular}{|c|c|c|}
\hline \multicolumn{3}{|l|}{ Marital status } \\
\hline Divorced & 9 & 6.8 \\
\hline Married & 76 & 57.6 \\
\hline Single & 39 & 29.5 \\
\hline Other & 8 & 6.1 \\
\hline Total & 132 & 100.0 \\
\hline \multicolumn{3}{|l|}{ Age group } \\
\hline Less 21 years & 3 & 2.3 \\
\hline $21-30$ years & 25 & 18.9 \\
\hline 31 - 40 years & 45 & 34.1 \\
\hline $41-50$ years & 47 & 35.6 \\
\hline $51-60$ years & 10 & 7.6 \\
\hline Above 60 years & 2 & 1.5 \\
\hline Total & 132 & 100.0 \\
\hline \multicolumn{3}{|c|}{ Highest level of education } \\
\hline SHS and below & 12 & 9.1 \\
\hline Diploma & 37 & 28.0 \\
\hline First degree & 58 & 43.9 \\
\hline Masters & 23 & 17.4 \\
\hline Ph.D. & 2 & 1.5 \\
\hline Total & 132 & 100.0 \\
\hline \multicolumn{3}{|c|}{ Type of employment } \\
\hline Not working & 8 & 6.1 \\
\hline Pensioner & 1 & 0.8 \\
\hline Salaried worker & 67 & 50.8 \\
\hline Self-employed & 56 & 42.4 \\
\hline Total & 132 & 100.0 \\
\hline
\end{tabular}


age of the respondents was 22.59 years old, with the majority of the students being in the age group 31 - 40 years old (67.3\%). In terms of the marital status, 76 (57.6\%) were married while $39(29.5 \%)$ were single. Most of the respondents were in the age category 41 - 50 years $(35.6 \%)$, followed by the age group $31-40$ years (34.1\%), 21 - 30 years (18.9\%), 51 - 60 years $(7.6 \%)$, less 21 years $(2.3 \%)$ and above 60 years (1.5\%). Concerning the highest education attained, 58 (43.9\%) reported having a first degree while 38 (28.0\%) reported having a diploma. Of the 132, a total of 67 (50.8\%) were salaried employees, 56 (42.4\%) were self-employed, $8(6.1 \%)$ were not working, while $1(0.8 \%)$ was a pensioner (Figures 1-5).

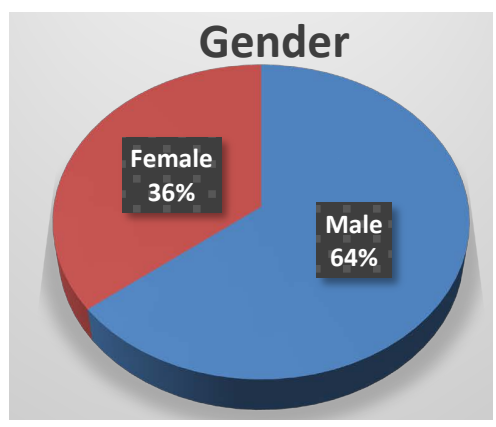

Figure 1. Respondents by gender.

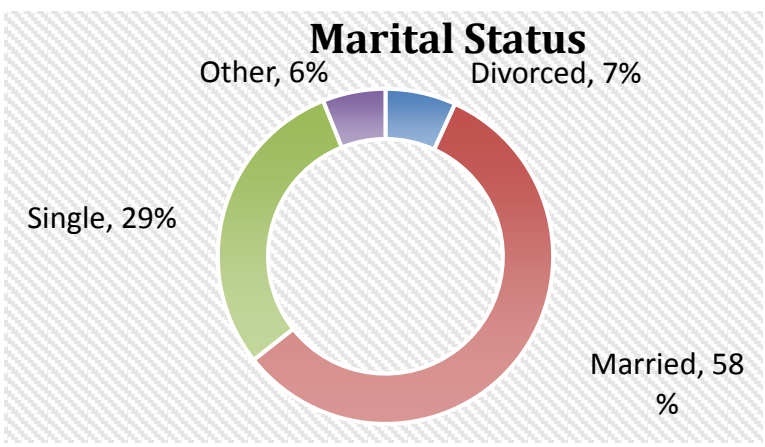

Figure 2. Respondents by marital status.

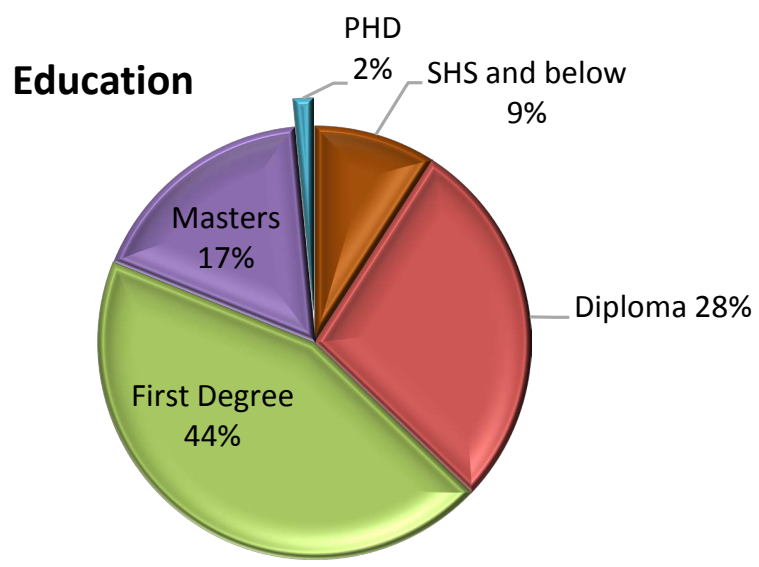

Figure 3. Respondents by educational qualification. 


\section{Frequency}

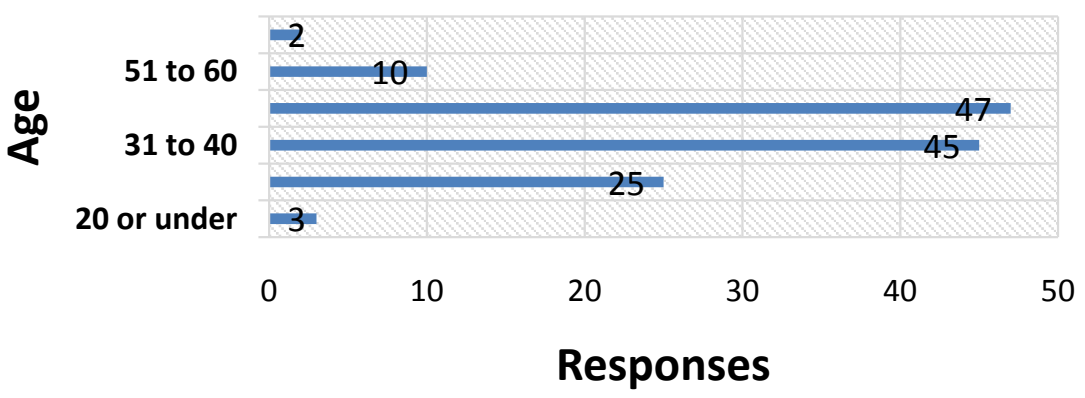

Figure 4. Respondents by age.

\section{Employment type}

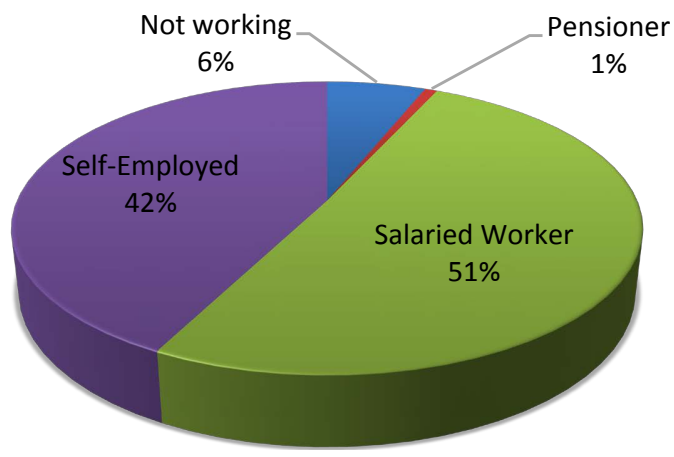

Figure 5. Respondents by employment type.

\subsubsection{Reliability and Factor Analysis}

To assure internal validity, the questionnaire comprised 25 items adapted from prior similar studies on both the dependent and independent variables. The questionnaire comprised 2 items on the adoption and use of e-PACRA services through the Government Service Bus (GSB), which was the dependent variable in the study. The independent variables were:

1) Performance Expectancy had 4 items

2) Effort Expectancy had 4 items

3) Social Influence had 5 times

4) Facilitating Conditions had 5 items

5) Behavioural Intention had 5 items

Items of the independent variables that required the respondents to rate were on a five-point Likert scale ranging from $1=$ "strongly disagree" to $5=$ "strongly Agree". The questionnaire was pilot tested before final distribution to ensure that the questions were concise and, where necessary, correctly rephrased.

Reliability analysis of all the variables included, representing all dimensions of factors affecting adoption and use of e-PACRA services through the Government Service Bus (GSB). All Cronbach's Alpha coefficients were above 0.7. Based on a study done by Mahiah, S. et al. (2006), this suggested that the items used in instruments were quite reliable. Items showing coefficients less than 0.7 
were excluded from the analysis.

Specifically, exploratory factor analysis with principal components extraction and varimax rotation was conducted. The assumptions for factorability of the data with coefficients above 0.3 were fulfilled since the Kaiser-Meyer-Olkin (KMO) measure of sampling adequacy was greater than the minimum value required of 0.60 , and the Bartlett's Test of Sphericity was significant (p-value < $0.05)$ for all the variables. Table 3 illustrates reliability and factor analysis.

\subsubsection{Hypothesis Results, Analysis, Interpretation and Model Building}

Hypothesis $1=\mathrm{X}_{1}$ : There is a positive relationship between performance expectancy and the adoption and use of e-PACRA services through the Government Services Bus (GSB) by users.

The relationship between performance expectancy and adoption and use of e-PACRA services through the GSB by users was investigated using Pearson correlation coefficient. The results in Table 6 indicate a very weak and positive relationship between performance expectancy and adoption and use of e-PACRA services through the Government Services Bus (R Square $=0.06, n=132, p>$ 0.05). This means that only 6 percent of the adoption and use of the e-PACRA services through the GSB is determined by performance expectancy but this cannot be taken literally because the relationship is not significant.

Hypothesis $2=\mathrm{X}_{2}$ : There is a positive relationship between effort expectancy and the adoption and use of e-PACRA services through the Government Service Bus (GSB) by users.

The results in Table 4 indicate a weak and positive relationship between effort expectancy and adoption and use of e-PACRA services through the Government Services Bus (R Square $=0.187, n=132, p<0.05$ ). This means that only 18.7 percent of the adoption and usage of e-PACRA services through the GSB is determined by effort expectancy since the relationship is significant.

Hypothesis $3=\mathrm{X}_{3}$ : There is a positive relationship between Social Influence

Table 3. Reliability and factor analysis.

\begin{tabular}{|c|c|c|c|c|c|c|c|c|}
\hline \multirow{2}{*}{ Variable Description } & \multirow{2}{*}{$\begin{array}{l}\text { No. of } \\
\text { items }\end{array}$} & \multirow{2}{*}{$\begin{array}{l}\text { Cronbach's } \\
\text { Alpha }\end{array}$} & \multirow{2}{*}{ Eigen value } & \multirow{2}{*}{$\begin{array}{c}\text { \% Variance } \\
\text { explained }\end{array}$} & \multirow{2}{*}{ KMO Test } & \multicolumn{3}{|c|}{ Bartlett's Test } \\
\hline & & & & & & Ap. Chi-square & $d f$ & Sig. \\
\hline \multicolumn{9}{|c|}{ Dependent variable } \\
\hline $\begin{array}{l}Y=\text { Adoption and use of } \\
\text { e-PACRA services through GSB }\end{array}$ & 8 & 0.875 & 4.326 & 54.702 & 0.885 & 2040.6 & 28 & 0.00 \\
\hline \multicolumn{9}{|c|}{ Independent variables } \\
\hline $\mathbf{X}_{\mathbf{1}}=$ Performance Expectancy & 4 & 0.816 & 2.644 & 66.089 & 0.685 & 240.7 & 6 & 0.00 \\
\hline $\mathbf{X}_{2}=$ Effort Expectancy & 4 & 0.782 & 2.424 & 60.592 & 0.778 & 139.8 & 6 & 0.00 \\
\hline $\mathbf{X}_{\mathbf{3}}=$ Social Influence & 5 & 0.730 & 2.789 & 55.77 & 0.730 & 273.7 & 10 & 0.00 \\
\hline $\mathbf{X}_{4}=$ Facilitating Conditions & 5 & 0.702 & 2.324 & 46.476 & 0.641 & 172.3 & 10 & 0.00 \\
\hline $\mathbf{X}_{5}=$ Behavioral Intention & 5 & 0.892 & 3.507 & 70.1 & 0.796 & 412.1 & 10 & 0.00 \\
\hline
\end{tabular}


Table 4. Analysis of hypotheses.

\begin{tabular}{|c|c|c|c|c|c|c|c|c|c|}
\hline \multicolumn{10}{|c|}{ Model Summary } \\
\hline \multirow{2}{*}{ Model } & \multirow{2}{*}{$\mathrm{R}$} & \multirow{2}{*}{ R Square } & \multirow{2}{*}{$\begin{array}{l}\text { Adjusted R } \\
\text { Square }\end{array}$} & \multirow{2}{*}{$\begin{array}{l}\text { Std. Error of } \\
\text { the Estimate }\end{array}$} & \multicolumn{5}{|c|}{ Change Statistics } \\
\hline & & & & & R Square Change & F Change & df1 & $\mathrm{df} 2$ & Sig. F Change \\
\hline 1 & $0.246^{\mathrm{a}}$ & 0.060 & 0.031 & 0.475 & 0.060 & 2.043 & 4 & 127 & 0.092 \\
\hline 2 & $0.432^{\mathrm{b}}$ & 0.187 & 0.134 & 0.449 & 0.126 & 4.773 & 4 & 123 & 0.001 \\
\hline 3 & $0.458^{c}$ & 0.210 & 0.123 & 0.452 & 0.023 & 0.688 & 5 & 118 & 0.634 \\
\hline 4 & $0.615^{\mathrm{d}}$ & 0.378 & 0.279 & 0.410 & 0.168 & 6.112 & 5 & 113 & 0.000 \\
\hline 5 & $0.683^{e}$ & 0.466 & 0.352 & 0.389 & 0.088 & 3.566 & 5 & 108 & 0.005 \\
\hline
\end{tabular}

a. Predictors: $\mathrm{X}_{1}=$ Performance Expectancy, b. Predictors: $\mathrm{X}_{2}=$ Effort Expectancy, c. Predictors: $\mathrm{X}_{3}=$ Social Influence, d. Predictors: $\mathrm{X}_{4}=$ Facilitating Conditions, and e. Predictors: $\mathrm{X}_{5}=$ Behavioural Intention.

and the adoption and use of e-PACRA services through the Government Service Bus (GSB) by users.

The results in Table 4 indicate a weak and positive relationship between Social Influence and the adoption and use of e-PACRA services through the Government Services Bus ( $\mathrm{R}$ Square $=0.21, n=132, p>0.05$ ). The relationship between the two variables is not significant.

Hypothesis $4=\mathrm{X}_{4}$ : There is a positive relationship between Facilitating Conditions and the use of e-PACRA services through the Government Service Bus (GSB) by users.

The results in Table 4 indicate strong and positive relationship between facilitating conditions and the adoption and use of e-PACRA services through the Government Services Bus (R Square $=0.378, n=132, p<0.05$ ). This means that only 37.8 percent of the adoption and usage of e-PACRA services through the GSB is determined by facilitating conditions since the relationship is significant.

Hypothesis $5=\mathrm{X}_{5}$ : There is a positive relationship between behavioural intention and the use of e-PACRA services through the Government Service Bus (GSB) by users.

The results in Table 4 indicate strong and positive relationship between behavioural intentions and the adoption and use of e-PACRA services through the government services bus ( $\mathrm{R}$ Square $=0.466, n=132, p<0.05$ ). This means that only 46.6 percent of the users of e-PACRA services through the GSB are determined by behavioural intentions since the relationship is significant.

\subsubsection{Model Building}

The hierarchical regression results in Table 5 and Table 6 below reveal the model development to address challenges or poor adoption and use of e-PACRA services through the GSB. The ANOVA table results show that all 4 of the 5 models are significant in explaining the adoption and use of e-PACRA services using GSB. The only invalid variable was performance expectancy while the rest were significant. 
Table 5. ANOVA ${ }^{\mathrm{a}}$.

\begin{tabular}{|c|c|c|c|c|c|c|}
\hline & Model & Sum of Squares & df & Mean Square & F & Sig. \\
\hline \multirow{3}{*}{1} & Regression & 1.847 & 4 & 0.462 & 2.043 & $0.092 b$ \\
\hline & Residual & 28.699 & 127 & 0.226 & & \\
\hline & Total & 30.545 & 131 & & & \\
\hline \multirow{3}{*}{2} & Regression & 5.703 & 8 & 0.713 & 3.529 & $0.001 c$ \\
\hline & Residual & 24.843 & 123 & 0.202 & & \\
\hline & Total & 30.545 & 131 & & & \\
\hline \multirow{3}{*}{3} & Regression & 6.406 & 13 & 0.493 & 2.409 & $0.006 \mathrm{~d}$ \\
\hline & Residual & 24.139 & 118 & 0.205 & & \\
\hline & Total & 30.545 & 131 & & & \\
\hline \multirow{3}{*}{4} & Regression & 11.545 & 18 & 0.641 & 3.814 & $0.000 \mathrm{e}$ \\
\hline & Residual & 19.000 & 113 & 0.168 & & \\
\hline & Total & 30.545 & 131 & & & \\
\hline \multirow{3}{*}{5} & Regression & 14.237 & 23 & 0.619 & 4.099 & $0.000 \mathrm{f}$ \\
\hline & Residual & 16.308 & 108 & 0.151 & & \\
\hline & Total & 30.545 & 131 & & & \\
\hline
\end{tabular}

a. Dependent Variable: $\mathrm{X}_{1}=$ adoption \& use of GSB, b. Independent variables: $\mathrm{X}_{1}=$ Performance Expectancy, $\mathrm{X}_{2}=$ Effort Expectancy, $\mathrm{X}_{3}=$ Social Influence, $\mathrm{X}_{4}=$ Facilitating Conditions, and $\mathrm{X}_{5}=$ Behavioural Intention.

Table 6. Hierarchical regression results.

\begin{tabular}{|c|c|c|c|c|c|c|}
\hline & \multirow[t]{2}{*}{ Model } & \multicolumn{2}{|c|}{$\begin{array}{l}\text { Unstandardized } \\
\text { Coefficients }\end{array}$} & \multirow{2}{*}{$\begin{array}{c}\begin{array}{c}\text { Standardized } \\
\text { Coefficients }\end{array} \\
\text { Beta }\end{array}$} & \multirow[t]{2}{*}{$\mathrm{T}$} & \multirow[t]{2}{*}{ Sig. } \\
\hline & & $\mathrm{B}$ & Std. Error & & & \\
\hline \multirow{5}{*}{1} & (Constant) & 2.066 & 0.267 & & 7.744 & 0.000 \\
\hline & $\begin{array}{l}\text { I think that the e-PACRA services on the GSB would be useful in } \\
\text { carrying out my tasks }\end{array}$ & -0.027 & 0.054 & -0.061 & -0.495 & 0.621 \\
\hline & $\begin{array}{l}\text { I think that using the e-Government Services (GSB) would enable me } \\
\text { conduct tasks better and quickly }\end{array}$ & -0.064 & 0.075 & -0.110 & -0.848 & 0.398 \\
\hline & I think using the GSB) would improve customer satisfaction among users & -0.073 & 0.087 & -0.114 & -0.840 & 0.403 \\
\hline & $\begin{array}{l}\text { I think using the GSB would provide improved customer care services } \\
\text { for PACRA clients }\end{array}$ & -0.005 & 0.075 & -0.008 & -0.063 & 0.950 \\
\hline \multirow{5}{*}{2} & (Constant) & 2.429 & 0.271 & & 8.977 & 0.000 \\
\hline & I think that interaction with the GSB is clear and easily understandable & -0.056 & 0.051 & -0.113 & -1.113 & 0.268 \\
\hline & I think it's easy to become skilful at using the GSB & -0.052 & 0.060 & -0.096 & -0.870 & 0.386 \\
\hline & I find the GSB platform easy to use & -0.120 & 0.057 & -0.240 & -2.106 & 0.037 \\
\hline & I think that learning to operate the GSB platform easy for me & -0.018 & 0.055 & -0.035 & -0.339 & 0.736 \\
\hline
\end{tabular}




\section{Continued}

(Constant)

People who influence my behaviour think that I should use the GSB

People who are important to me think that I should use the GSB

People who use the GSB for e-PACRA services have more prestige than

3 those who do not

People's attitude towards the use of the GSB for e-PACRA services feel that they are prestigious

People's attitude towards the use of the GSB for e-PACRA services makes me feel like they are more educated

(Constant)

I have the resources necessary to use the GSB to access e-PACRA services

I have the knowledge necessary to use the GSB to access e-PACRA services

4 Help/guidance is available on using e-PACRA services on the GSB

The GSB platform has most of the e-PACRA services I need

I am aware and understand the e-PACRA services that can be accessed on the GSB

(Constant)

I intend to use the GSB system in the next few months in order to improve my customer service experience at PACRA

I predict I would use the GSB in the next few months to enhance my

5 customer service experience at PACRA

I plan to use the GSB system in the next few months with a view of enhancing my customer service experience at PACRA

I intend to resolve my queries using e-PACRA services on the GSB

I intend to enquire on my PACRA services using the GSB

$\begin{array}{ccccc}2.329 & 0.296 & & 7.879 & 0.000 \\ 0.017 & 0.049 & 0.041 & 0.346 & 0.730 \\ 0.086 & 0.063 & 0.180 & 1.383 & 0.169 \\ & & & & \\ -0.029 & 0.056 & -0.071 & -0.525 & 0.600\end{array}$

$\begin{array}{lllll}0.028 & 0.059 & 0.064 & 0.483 & 0.630\end{array}$

$\begin{array}{lllll}-0.028 & 0.059 & -0.064 & -0.475 & 0.635\end{array}$

$\begin{array}{llll}2.380 & 0.273 & 8.715 & 0.000\end{array}$

$\begin{array}{lllll}-0.011 & 0.047 & -0.025 & -0.239 & 0.811\end{array}$

$\begin{array}{lllll}-0.244 & 0.050 & -0.502 & -4.891 & 0.000\end{array}$

$\begin{array}{lllll}0.097 & 0.048 & 0.209 & 2.026 & 0.045\end{array}$

$\begin{array}{lllll}0.032 & 0.060 & 0.065 & 0.539 & 0.591\end{array}$

$\begin{array}{lllll}0.004 & 0.051 & 0.010 & 0.083 & 0.934\end{array}$

\begin{tabular}{lllll}
2.529 & 0.282 & & 8.968 & 0.000 \\
-0.192 & 0.092 & -0.328 & -2.088 & 0.039 \\
& & & & \\
-0.142 & 0.092 & -0.225 & -1.542 & 0.126 \\
& & & & \\
0.062 & 0.087 & 0.092 & 0.712 & 0.478 \\
-0.017 & 0.070 & -0.031 & -0.244 & 0.808 \\
0.094 & 0.077 & 0.152 & 1.222 & 0.224 \\
\hline
\end{tabular}

Based on the regression results shown in Table 6, it can be seen that models 2, 4 and 5 each had at least 1 item showing significance $(p<0.05)$ with regards to explaining e-PACRA adoption and use through the GSB. Thus, the items that can be used to build a sound model based on the results of the study are:

$\mathrm{X}_{2}$ : Effort Expectancy(I find the GSB platform easy to use)

$\mathrm{X}_{4}$ : Facilitating Conditions

I have the knowledge necessary to use the GSB to access e-PACRA services

Help/guidance is available on using e-PACRA services on the GSB

$\mathrm{X}_{5}$ : Behavioural Intention (I intend to use the GSB system in the next few months in order to improve my customer service experience at PACRA)

\section{Discussion Linking the UTAUT Model to the Study Results}

The main objective of this research study was to identify the factors from the UTAUT model that affect PACRA customers' adoption and use of the e-PACRA 
services on the e-Government platform called the Government Service Bus. The results revealed that the UTAUT could explain PACRA customers' behavior in relation to adoption and usage of the e-PACRA services and that all but one of the relationships posited in the UTAUT were supported (Abbad, 2021). Social influence strikingly did not influence adoption and use of the system, which is consistent with other findings in technology acceptance research results as "Not supported" (Jambulingam, 2013) and in e-government contexts (Abbad, 2021).

However, according to (Al-Adwan et al., 2018), "literature suggests that the impact of social influence will be significant in the initial phases of m-learning and will gradually decrease over time as m-learning becomes more widely used," which was contrary to our findings in my study. This research result implies that social influence is not a significant predictor of the adoption and actual use of the system. The current digital generation was born into a digital environment where peer influence was less necessary (Jambulingam, 2013).

However, it was noted that accessing devices and or internet broadband was considered a challenge for most members of society in Zambia.

Performance Expectancy was also another predictor that was not an influence on the adoption and actual use of e-PACRA services on the GSB platform.

Due to these findings, it is essential that academicians, experts, administrators and designers of e-PACRA services on the GSB system to focus on promoting the efficiency and efficacy of a system that enhances PACRA customers' main influencing constructs as shown in the hierarchical regression analysis results in Table 6.

Effort expectancy was the third most important determinant of adoption and use of the e-PACRA services. Similar results have been found by researchers using a different adoption model (e.g., TAM) in information technology contexts (Abbad, 2021). When building and/or modifying the e-PACRA services on the GSB, PACRA and SZI should therefore take this factor into consideration and make it as easy to use as possible (less effort) so that PACRA customers are motivated to adopt and use it. Facilitating conditions also significantly appeared to support PACRA customers' $37.8 \%$ adoption and actual use of e-PACRA services on the GSB.

These findings are consistent with several previous studies in technology acceptance studies (Al-Adwan et al., 2018). PACRA customers will use e-PACRA services through the GSB when the necessary resources and technical support are perceived to be available or provided. PACRA and SZI should motivate PACRA customers to use the e-PACRA services on the e-Government Platform (GSB) through the provision of advertising, training, documents, and technical support where needed. Supportive and knowledgeable staff should be available at any time to help customers overcome any difficulties they may encounter.

The primary goal of this study was to use the UTAUT framework to assess the effectiveness and influence of the predictors on the (e-PACRA) services based on PACRA customers' acceptance of technology. The results showed that effort ex- 
pectancy, facilitating conditions, and behavioral intentions had a positive impact on influencing the adoption and use of the e-PACRA services. Performance expectancy and social influence did not have any meaningful effect on the adoption and actual use of the e-PACRA services on the GSB.

Finally, it is worth noting that behavioral intentions had the most direct and significant effect on customers' adoption and actual use of the online system. The fact that behavioral intentions had a strong effect on usage shows that those customers with high levels of behavioral intentions had high levels of adoption and usage of the e-PACRA services through the GSB.

Alshehri et al. (2012) also discovered similar results regarding behavior intentions to use e-government services in acceptance of new technologies. In addition, performance expectancy was the least important determinant of customer behavior. This suggests that customers at $6 \%$ influence on the adoption and actual use of the system, performance expectancy didn't help them much to complete their tasks.

A clearer understanding of the determinants of the adoption and actual use of e-PACRA services by customers will help decision makers at PACRA and SZI use the right technology and encourage customers to engage with the system by building and designing a technological environment that will help them enhance their interest in adopting and using the system. This is especially vital during such an unprecedented era of the COVID-19 pandemic, which has impelled institutions across the world to make use of E-Systems.

\section{Conclusion}

E-Governance has enabled governments all over the world to provide services that are as competitive, if not better, than those provided by corporate businesses in certain circumstances. Despite being non-profit instituions, governments have seen it fit to tap into innovative electronic solutions to provide user friendly services to their clientele. The adoption of such technology as the Government Service Bus has even further enhanced service delivery by allowing customers to access various services like form applications, payments online, and many more. All this is without human interaction and intervention. This can be seen from services like road tax, motor vehicle licensing, etc. from RTSA, Immigration, and the Zambia Police that provide various services that can be conducted online through the Government Service Bus platform. Day-to-day administrative operations have also been incorporated, and resource personnel have heightened their productivity and efficiency in doing their jobs using technology. PACRA, as a government agency that provides services to the general public and corporate world, has benefited from the e-governance initiative in Zambia. However, the generally low uptake of e-Government services hasn't spared PACRA as an institution and therefore it became prudent to undertake a study to find out factors affecting the adoption and use of e-PACRA services through the GSB based on the UTAUT Model. 
The research results using SPSS therefore revealed that performance expectancy, effort expectancy, and social influence had a positive weak correlation with the actual use of e-PACRA services. Facilitating conditions and behavioral intentions exhibited a strong positive relationship with the adoption and actual use of e-PACRA services. The study shows us that 4 out of 5 predictors significantly influence the adoption and use of e-PACRA services and can be used to improve the adoption rate. However, for future models, 3 out 5 were very significant to build a model with positive adoption results.

The reason behind this research study was primarily to investigate and identify the determinants of PACRA customers' behavior in relation to the adoption and use of e-PACRA services on the e-Government platform (GSB), hence the topic "The Factors Affecting the Adoption of e-PACRA Services through the Government Service Bus (GSB).” The results of the research study suggest that PACRA customers' adoption and actual use of e-PACRA services through the GSB is predicted and determined through direct or indirect relationship to actual use. Effort expectancy is indirectly linked, while facilitating conditions and behavioral intentions are directly linked to the actual use of the e-System. The results also indicate that both facilitating conditions and behavioral intentions had a significant effect on actual use of e-PACRA services. In the context of PACRA and SZI, this research affirms the utilization of the UTAUT framework/Model in predicting factors affecting the adoption and use of e-PACRA services by customers in developing countries like Zambia.

Given these results, PACRA and SZI should encourage PACRA customers to use e-PACRA services to enhance the low uptake of e-services on the e-Government platform (GSB). The successful implementation of the system depends on PACRA customers' acceptance of the technology and how they embrace it. It is therefore necessary for management, administrators and developers of e-PACRA services through the GSB to design effortless and user-friendly applications to encourage and motivate PACRA online customer uptake on the platform. PACRA and SZI management should ensure that all the required resources are available for PACRA customers/clients, designers and technical support staff when needed. This will help PACRA and SZI to react immediately in the event of any changes to the system if required or in the case of an emergency such as COVID-19's multifaceted effects on human life and the world over.

\section{Limitations}

The study was limited to the capital city of Zambia, Lusaka. As for academic research, restrictions due to resources and sites were a limitation. Zambia currently has 10 provinces, but only a section of Lusaka was considered in this study.

With the UTAUT having PE, SI, EE, FC, and BI as independent variables, potential determinants, namely, age, gender, experience, and voluntariness of use, could have a bearing on strengthening the prediction of PACRA customers' be- 
havior but were not taken into consideration. This effectively narrowed the scope of the study and is a limitation in and of itself.

\section{Recommendations}

- PACRA should increase awareness of the use of e-PACRA services through front line officers and increased advertising.

- PACRA should consider the use of GSB as a platform for customers to easily access the services even with low-speed internet connections to increase the user base.

- PACRA should also critically consider the three identified model building predictors from the UTAUT framework to help improve service delivery, adoption and use of e-PACRA services through the GSB.

- PACRA could also gradually increase mandatory access to e-PACRA services, compelling clients to use the system. This might seem unorthodox or too drastic, but due to human nature and with change being philosophically abhorrent to human nature or not easily acceptable, a theory of utilitarianism might bring about transformative change to the way PACRA customers do business. As evidenced by a memo at PACRA head office, a list of services to be accessed on the e-PACRA platform has been pasted on the notice board.

- It is also recommended that further study should be done on factors affecting the e-PACRA services through the GSB in all provinces of Zambia with the view to increasing knowledge and cementing findings of this subject/study going forward.

- A study could further be undertaken, widening the scope of moderators to include age, gender, experience, and voluntariness of use as variables.

- Although this study discussed the role of the UTAUT model in the conceptual framework development, the moderators in the UTAUT model are not all included. Therefore, future studies could consider these indirect moderators as variables that might influence the adoption and use of e-PACRA services on the e-government platform in Zambia.

\section{Acknowledgements}

I acknowledge the valuable assistance and support of all my associates who participated in this research and who have indeed encouraged me till this day. Special gratitude goes to my mother, my supervisor, and my family. Many thanks also go to the Graduate School of Business and its entire staff (the year 2021).

\section{Conflicts of Interest}

The authors declare no conflict of interest regarding the publication of this paper.

\section{References}

Abbad, M. M. (2021). Using the UTAUT Model to Understand Students' Usage of 
e-Learning Systems in Developing Countries. Education and Information Technologies, 26, 7205-7224. https://doi.org/10.1007/s10639-021-10573-5

Ahmad, M. I. (2014, December 20-22). Unified Theory of Acceptance and Use of Technology (UTAUT): A Decade of Validation and Development. Alexandria University. https://www.researchgate.net/publication/270282896 Unified Theory of Acceptance and Use of Technology UTAUT A Decade of Validation and Development

Ajzen, I. (1991). The Theory of Planned Behavior. Organization Behavior and Human Decision Processes, 50, 179-211. https://doi.org/10.1016/0749-5978(91)90020-T

Al-Adwan, A. S., Al-Madadha, A., \& Zvirzdinaite, Z. (2018). Modeling Students' Readiness to Adopt Mobile Learning in Higher Education: An Empirical Study. International Review of Research in Open and Distributed Learning, 19, 222-241.

https://doi.org/10.19173/irrodl.v19i1.3256

Al-Qeisi, K. I. (2018). Analyzing the Use of UTAUT Model in Explaining an Online Behaviour: Internet Banking Adoption. Brunel University. https://bura.brunel.ac.uk/bitstream/2438/3620/1

Alshehri, M., Drew, S., \& AlGhamdi, R. (2012). Analysis of Citizens Acceptance for e-Government Services: Applying the UTAUT Model. International Conferences Theory and Practice in Modern Computing and Internet Applications and Research (pp. 69-76).

https://www.researchgate.net/publication/258841651 Analysis of Citizens Acceptanc e for E-government Services Applying the UTAUT Model

Bwalya, K. J., \& Healy, M. (2010). Harnessing e-Government Adoption in the SADC Region: A Conceptual Underpinning. Electronic Journal of e-Government, 8, 23-32.

Chao, C.-M. (2019). Factors Determining the Behavioral Intention to Use Mobile Learning: An Application and Extension of the UTAUT Model. Frontiers in Psychology, 10, Article No. 1652. https://doi.org/10.3389/fpsyg.2019.01652

Chipeta, J. (2018). A Review of E-Government Development in Africa: A Case of Zambia. Journal of e-Government Studies and Best Practices, 2018, Article ID: 973845.

Cochran, W. (1977). Sampling Techniques (3rd ed.). John Wiley \& Sons.

Creswell, W. J. (2012). Educational Research: Planning, Conducting and Evaluating Quantitative and Qualitative Research (4th ed.). Pearson.

Daka, G. C., \& Phiri, J. (2019). Factors Driving the Adoption of E-Banking Services Based on the UTAUT Model. International Journal of Business and Management, 14, 43-52. https://doi.org/10.5539/ijbm.v14n6p43

Jambulingam, M. (2013). Behavioural Intention to Adopt Mobile Technology among Tertiary Students. World Applied Sciences Journal, 22, 1262-1271.

Kumar, V., Mukerji, B., \& Ajax, P. (2007). Factors for Successful e-Government Adoption: A Conceptual Framework. The Electronic Journal of e-Government, 1, 63-77.

Lishomwa, L., \& Phiri, J. (2020). Adoption of Internet Banking Services by Corporate Customers for Forex Transactions Based on the TRA Model. Open Journal of Business and Management, 10, 329-345. https://doi.org/10.4236/ojbm.2020.81020

Mahiah, S., Suhaimi, S., \& Ibrahim, A. (2006). Measuring the Level of Customer Satisfaction among Employees of Human Resource Division. Advances in Global Business Research, 3 .

Martins et al. (2014). Understanding the Internet Banking Adoption: A Unified Theory of Acceptance and Use of Technology and Perceived Risk Application. International Journal of Information Management, February, 34, 1-13. 
https://doi.org/10.1016/j.ijinfomgt.2013.06.002

Nkwe, N. (2012). E-Government: Challenges and Opportunities in Botswana. International Journal of Humanities and Social Science, 2, 39-48.

Nuwagaba, A., \& Ngoma, B. (2014). Analysis of E-Banking as a Tool to Improve Banking Services in Zambia. International Journal of Business and Management Invention, 3, 62-67.

Office of the Vice President (2019). National Assembly of Zambia. https://www.parliament.gov.zm/node/8089

PACRA (2020). Annual Report. PACRA.

Sarmah, H. K., Hazarika, B. B., \& Choudhury, G. (2013). An Investigation on Effect of Bias on Determination of Sample Size on the Basis of Data Related to the Students of Schools of Guwahati. International Journal of Applied Mathematics \& Statistical Sciences, 2, 33-48.

Sikaonga, S., \& Tembo, S. (2020). E-Government Readiness in the Civil Service: A Case Study of Zambian Ministries. International Journal of Information Science, 10, 15-28.

Smart Zambia Institute (2020). Stakeholder Meeting and Press Briefing on the Government Service Bus and Payment Gateway System. Smart Zambia Institute.

TDRA (2021). Government Service Bus (GSB). https://u.ae/en/information-and-services/g2g-services/government-services-bus

The World Bank (2020). Accelerating Digital Transformation in Zambia. The World Bank (IBRD-IDA).

Venkatesh, V., Morris, M. G., Davis, G. B., \& Davis, F. D. (2003). User Acceptance of Information Technology: Toward a Unified View. MIS Quarterly, 27, 425-478.

https://doi.org/10.2307/30036540 